\title{
Similarities and Differences in Implicit Personality Concepts across Ethnocultural Groups in South Africa
}

\author{
Velichko H.Valchev', J.Alewyn $\mathrm{Nel}^{2}$, \\ Fons J. R. van de Vijver ${ }^{1,2,5}$, Deon Meiring ${ }^{3}$, Gideon P. de Bruin ${ }^{4}$, \\ and Sebastiaan Rothmann ${ }^{2}$
}

\begin{abstract}
Using a combined emic-etic approach, the present study investigates similarities and differences in the indigenous personality concepts of ethnocultural groups in South Africa. Semistructured interviews asking for self- and other-descriptions were conducted with I,027 Blacks, 58 Indians, and 105 Whites, speakers of the country's II official languages. A model with 9 broad personality clusters subsuming the Big Five-Conscientiousness, Emotional Stability, Extraversion, Facilitating, Integrity, Intellect, Openness, Relationship Harmony, and Soft-Heartedness (Nel et al., 20I2) - was examined. The 9 clusters were found in all groups, yet the groups differed in their use of the model's components: Blacks referred more to social-relational descriptions, specific trait manifestations, and social norms, whereas Whites referred more to personal-growth descriptions and abstract concepts, and Indians had an intermediate pattern. The results suggest that a broad spectrum of personality concepts should be included in the development of common personality models and measurement tools for diverse cultural groups.
\end{abstract}

\section{Keywords}

implicit personality concepts, emic-etic approach, indigenous personality model

Cross-cultural research on personality is traditionally conducted either from an etic (universalistic) or an emic (culture-specific) perspective (Cheung, Van de Vijver, \& Leong, 2011; Church, 2008). In more recent studies, there is a tendency to seek an integration of the two perspectives in an emic-etic framework that recognizes indigenous as well as universal components of personality (Cheung et al., 2011). The present study investigates a recently developed indigenous model of personality for South Africa (Nel et al., 2012) in an emic-etic framework. This model has been

\footnotetext{
'Tilburg University, Tilburg, the Netherlands

${ }^{2}$ North-West University, Potchefstroom, South Africa

${ }^{3}$ University of Pretoria, Pretoria, South Africa

${ }^{4}$ University of Johannesburg, Johannesburg, South Africa

${ }^{5}$ University of Queensland, Brisbane, Australia

Corresponding Author:

Velichko H.Valchev, Tilburg University, PO Box 90153 ,Tilburg, 5000 LE, the Netherlands.

Email:v.h.valchev@uvt.nl
} 
developed from an indigenous perspective to represent the implicit personality concepts of all major cultural groups in South Africa. The salience of the specific elements of this model for different groups has not been addressed so far, although group differences can be expected both as a function of broad factors like individualism-collectivism (Triandis, 1995), autonomy-embeddedness, and egalitarianism-hierarchy values (Schwartz, 2006) and of more specific factors like cultural differences in definitions of intelligence (Serpell, 1993). This study explores the similarities and differences in the salience and composition of implicit personality concepts across three ethnocultural groups in South Africa: Blacks, Indians, and Whites. We first provide a brief overview of the emic-etic approaches to personality. We then sketch the background of personality study in South Africa and describe in detail the indigenous model under investigation.

\section{Emic-Etic Approaches to Personality}

Etic studies of personality are primarily concerned with the cross-cultural replicability of universal personality models (Church, 2001, 2008). These studies typically employ questionnaires measuring a model developed in a Western context such as the Big Five or Five-Factor Model (FFM) in an array of cultures and, when replicability is adequately established, compare mean levels of the personality traits under that model across cultures. A typical example of this approach can be found in the studies by McCrae and colleagues, who have provided impressive evidence for the replicability of the FFM (e.g., Allik \& McCrae, 2004; McCrae \& Allik, 2002; McCrae, Terracciano, \& 79 Members of the Personality Profiles of Cultures Project, 2005).

Emic studies, on the other hand, direct their attention to the identification of personality concepts that are especially relevant in specific cultural contexts, although they may not be represented in universal models. These studies often start with an exploration of implicit personality concepts using qualitative methods and the study of lexica and later develop questionnaires to represent the implicit model (Church, 2008). Examples of this approach can be found in the studies of Church and colleagues in Mexico (Ortiz et al., 2007) and the Philippines (Katigbak, Church, GuanzonLapeña, Carlota, \& Del Pilar, 2002) and Cheung and colleagues in China (Cheung et al., 2001). While the former two studies have largely confirmed the Big Five from an emic perspective, Cheung and colleagues' research has identified a dimension especially relevant in China and which could not be subsumed under the Big Five, namely Interpersonal Relatedness (Cheung et al., 2001).

Recently, efforts have been made toward a more integrated, emic-etic approach where culturespecific and universal models are viewed as complementary (Cheung et al., 2011). One way of achieving such integration can be found in lexical studies, where models are derived separately per language and their factor structures are subsequently tested for structural equivalence (Saucier \& Goldberg, 2001). Lexical studies have been used both to identify dimensions beyond the Big Five (e.g., Lee \& Ashton, 2008) and to identify the most replicable personality dimensions (De Raad et al., 2010). A limitation of this approach is that there is only partial overlap in the stimuli that can be compared across languages (De Raad et al., 2010). A different approach is to develop questionnaires that measure indigenous personality concepts in a given culture and use them for comparisons with other cultures. For example, the indigenous model first identified in China by Cheung et al. (2001) was later replicated in Chinese American and European American participants (Lin \& Church, 2004), indicating that the concept of interpersonal relatedness, although more relevant in a Chinese context, is also recognized in other contexts. The broad project that the present study is placed in - the South African Personality Inventory (SAPI) project ${ }^{1}$ — is another example of the emic-etic approach. Starting from free descriptions of personality, this project has developed a common indigenous personality model that represents the main personality concepts in the 11 official languages of South Africa (Nel et al., 2012). The present study starts from this common model and investigates differences in the salience of its components across three ethnocultural groups of South Africa. 


\section{Personality Study in South Africa}

South Africa is a multicultural society. The Apartheid-era distinction of four "ethnic" groups is still in use, namely "Black" (for people of African descent), "Coloured" (mixed-race descent), "Indian" (or Asian, for descendants of immigrants from India and South-East Asia), and "White" (European descent). There are 11 official languages: two Germanic languages (Afrikaans and English, spoken as a first language by Coloureds, Indians, and Whites, constituting $21.5 \%$ of the country's population) and nine Bantu languages (Northern Sotho, Southern Sotho, Tswana, Ndebele, Swati, Xhosa, Zulu, Tsonga, and Venda, spoken as a first language by Blacks, 77.9\% of the population; Statistics South Africa, 2001).

This rich cultural diversity has not been adequately represented in personality research in South Africa. The imposed-etic tradition, based on tests imported from English-speaking countries, notably the United States and the United Kingdom, has a strong presence. Such tests have hardly been adapted to the local context (Foxcroft, Paterson, Le Roux, \& Herbst, 2004) and have often been found to have poor psychometric properties in the indigenous African groups (e.g., Meiring, Van de Vijver, Rothmann, \& Barrick, 2005). In one of the few studies of local test development, Taylor and De Bruin (2005) developed an instrument specifically designed to measure the FFM taking local context into account. These authors found comparable factor structures and reliability values across cultural groups in South Africa, suggesting that the FFM is replicable across these groups when assessed with culturally valid stimuli. None of these studies, however, has investigated indigenous personality concepts beyond Western models.

In the first indigenous personality study for South Africa, we derived implicit personality concepts from interviews conducted with participants from the country's 11 official languages (Nel et al., 2012). The descriptions made in these interviews were categorized based on their semantic proximity and co-occurrence patterns into concepts at different levels of abstraction, from narrower to broader traits: 188 facets, 37 subclusters, and 9 clusters. The nine clusters were: Conscientiousness, Emotional Stability, Extraversion, Facilitating, Integrity, Intellect, Openness, Relationship Harmony, and Soft-Heartedness. The clusters had a good correspondence to the Big Five, with a few differences. Intellect and Openness were split in two because of their distinct content (cf. De Raad \& Van Heck, 1994). Integrity was similar to the HEXACO model's Honesty (Ashton \& Lee, 2001), although Integrity placed more emphasis on fairness and discrimination. Relationship Harmony and Soft-Heartedness were similar to Agreeableness but included more concepts than are typically found under the Agreeableness label. Finally, Facilitating, referring to the qualities of being a good guide in life and having beneficial influence on others, is not well represented in Western models. The model suggested an emphasis on concepts dealing with the quality of interpersonal relations; the model was largely supported in a quantitative study involving similarity ratings of the 37 subclusters, although several social-relational concepts did not replicate in detail (Nel et al., 2012). It is important to note that the model was developed to represent the implicit concepts of all 11 languages: The nine clusters and 37 subclusters were based on personality descriptions occurring in all languages; 150 out of the 188 facets occurred in at least seven languages, and there were only 10 facets occurring in one or two languages. This allows us to make comparisons of the salience of the model's components across different groups.

\section{Personality Differences Across Ethnocultural Groups}

Overarching Framework. The present study explores how groups in South Africa differ with respect to the salience of the components of the indigenous personality model ( $\mathrm{Nel}$ et al., 2012). In a study on the use of traits (vs. nontrait descriptions) across groups, we found that speakers of the 11 languages could be meaningfully grouped into three ethnocultural groups: Blacks, Coloureds and Indians, and Whites (Valchev et al., 2012). Predictions from the 
individualism-collectivism framework (Triandis, 1995) were confirmed: Blacks made the least use of traits and the most use of behaviors, preferences, and perceptions for personality description; the opposite was true for Whites, whereas Coloureds and Indians had an intermediate pattern. In the present study, we examine the use of the categories of the indigenous model by Blacks, Indians, and Whites. ${ }^{2}$ The three groups can be taken to lie on a continuum from more collectivistic (Blacks) through intermediate (Indians) to more individualistic (Whites) and can be expected to differ in a similar way along Schwartz's (2006) autonomy-embeddedness and egalitarianism-hierarchy value continuums. This ordering of South Africa's major ethnocultural groups is in line with previous research; in particular, the distinction between the Black and White groups is well documented in various domains (Allik \& McCrae, 2004; Eaton \& Louw, 2000; Laher, 2008; Seekings, 2008).

The present study investigates cross-cultural differences in personality concepts using free personality descriptions. The strength of this method is that it provides more direct evidence of the salience of specific personality concepts than standardized questionnaires, because it employs the frequency with which these concepts are mentioned. Previous studies on spontaneous selfdescriptions have failed to find cross-cultural differences in the references to the Big Five categories predicted from an individualism-collectivism perspective (Ip \& Bond, 1995; Watkins \& Gerong, 1997). A likely explanation is that each of the Big Five dimensions subsumes both agentic and communal elements, which may differ in salience in different groups (Del Prado et al., 2007; Sedikides, Gaertner, \& Toguchi, 2003; Wiggins \& Trapnell, 1996). Indeed, associations between personality traits and individual-level values have been most successfully demonstrated when examining facets rather than broad factors of the FFM (e.g., Roccas, Sagiv, Schwartz, \& Knafo, 2002). Another possible explanation is the use of an etic model: Meaningful cross-cultural differences may be more likely to be revealed when the groups are compared using indigenously derived models (e.g., Cheung et al., 2001; Lin \& Church, 2004). Finally, the theoretical links between some broad personality factors and broad value dimensions may be hard to establish (e.g., Roccas et al., 2002, on Neuroticism). When lower level traits are concerned, predictions from more specific theoretical models may be more informative. For example, cultural differences can be expected in the domain of Intellect and Openness, where literature suggests less structural equivalence across cultural groups than in the other personality dimensions (Church, 2008) and increased emphasis on specific aspects of intelligence in African cultures (Serpell, 1993). In the present study, we investigate cross-cultural differences in the salience of the components of South Africa's indigenous personality model, going from the broad level of nine clusters to the narrow level of 188 facets. This study combines emic and etic aspects. It is emic in its employment of indigenous concepts, derived by means of semistructured qualitative techniques and not based on already existing models. The study is also etic in that these indigenous concepts were derived across different ethnocultural groups in South Africa and define shared categories that can be used for cultural comparisons. The expected patterns are described in the following paragraphs.

Hypotheses and Their Background. We employ a distinction between primarily agentic or personal-growth clusters (Conscientiousness, Extraversion, Intellect, and Openness), communal or social-relational clusters (Facilitating, Relationship Harmony, and Soft-Heartedness), and clusters that are harder to assign to one of the two categories (Emotional Stability and Integrity). Previous studies have demonstrated cross-cultural differences in the use of agentic and communal self-concept attributes. For example, Sedikides et al. (2003) found that Americans and participants with independent self-construals self-enhanced more on agentic attributes, whereas Japanese and participants with interdependent self-construals self-enhanced more on communal attributes. Accordingly, we expect that the personal-growth clusters are used more frequently by the more individualistic White group and less frequently by the more collectivistic Black group, 
with Indians in the middle. The opposite pattern is expected for the social-relational clusters, and we do not specify hypotheses about the salience of the two more ambivalent clusters. Differences can also be expected in the extent to which the lower level components of the clusters are used by the different groups.

Our distinction of personal-growth and social-relational clusters is in agreement with empirical (Digman, 1997) and conceptual (Ashton \& Lee, 2001) categorizations of the major personality dimensions as well as with studies on the associations of these dimensions with values (McCrae et al., 2005; Roccas et al., 2002) and self-perception biases (Paulhus \& John, 1998; Paulhus \& Trapnell, 2008). The categorization is more straightforward for some of the clusters than others, as elaborated below.

Personal-growth clusters. There is general agreement over the classification of Extraversion, Intellect, and Openness as primarily agentic or person-focused personality concepts (e.g., Ashton \& Lee, 2001; Digman, 1997). These concepts have been found to be associated with individualism (McCrae et al., 2005), values of personal growth (Roccas et al., 2002), and agentic selfpresentation biases (Paulhus \& John, 1998). We expect all facets of these clusters to be used more frequently in the White group and less frequently in the Black group, with Indians in the middle, with one exception in the Intellect cluster. Intellect includes, besides conventional intellect facets, also practical and social intelligence, which has been suggested as particularly salient in native African groups (Serpell, 1993; Valchev et al., 2011). We expect that these facets are used more frequently by Blacks and less frequently by Whites, with Indians in the middle, while the reverse is expected for all other facets of Intellect.

Conscientiousness combines concepts that could be characterized as rather agentic with others that are rather communal. Employing a distinction between ambition and dutifulness elements of Conscientiousness, Paulhus and John (1998) found that ambition was more strongly associated with agency biases and dutifulness with communion biases in self-perception. Roccas et al. (2002) demonstrated a similar contrast in the associations of proactive and inhibitive aspects of Conscientiousness with achievement and conformity values, respectively. In our indigenous model, Conscientiousness is mostly defined by achievement and diligence elements (Nel et al., 2012; Valchev et al., 2011), and we hence expect the cluster to be more salient in Whites' descriptions than in Blacks'. On the level of facets, achievement-related facets are expected to be used more frequently by Whites and less frequently by Blacks, with Indians in between. The opposite pattern is expected for facets about preserving order and tradition.

Social-relational clusters. Relationship Harmony, Soft-Heartedness, and Facilitating (interpreted as variations of the Agreeableness domain) are considered primarily communal or relationshipfocused, in accordance with existing literature on the higher order categorization of Agreeableness (Ashton \& Lee, 2001; Digman, 1997) and its associations with communal self-presentation biases (Paulhus \& John, 1998) and values of conformity and benevolence (Roccas et al., 2002). Possibly the only finding in an opposite direction is that of McCrae et al. (2005), who found a positive association of country-level Agreeableness with individualism. These authors discussed this pattern as contrary to predictions and acknowledged that their data provide "more evidence for the construct validity of aggregate O[penness] than of aggregate A[greeableness]" (McCrae et al., 2005, p. 423). Given the content of Relationship Harmony, Soft-Heartedness, and Facilitating, dealing with the quality of social relations, we expect these clusters and their facets to be more salient in the Black group and less salient in the White group, with Indians in the middle.

Emotional stability and integrity. We do not formulate a hypothesis for Emotional Stability at the cluster level. Emotional Stability has not been found to have systematic relations with culturelevel values except uncertainty avoidance (McCrae et al., 2005) and is relatively neutral with respect to agentic-communal self-presentation biases (Paulhus \& Trapnell, 2008). However, Emotional Stability contains different components for which opposite predictions can be made. 
A distinction has been made, using various terms, between internalizing and externalizing elements, differentiating between inward and outward direction of negative affect (DeYoung, Quilty, \& Peterson, 2007; Roccas et al., 2002; Saucier \& Goldberg, 2001). We expect that the internalizing elements, more strongly associated with autonomous functioning, are more salient in the more individualistic White group, whereas the externalizing elements, more strongly associated with social functioning, are more salient in the more collectivistic Black group, with Indians in between.

Integrity has some relation to the Honesty factor of Ashton and Lee's (2001) HEXACO model (accounting for terms between the Big Five's Agreeableness and Conscientiousness axes), but also includes elements of fairness and discrimination. Integrity concepts could be expected to be salient, although possibly with different connotations, in cultures high either on autonomy and egalitarianism, or on embeddedness and hierarchy. For example, in a multidimensional scaling analysis of the Rokeach values by Vauclair, Hanke, Fischer, and Fontaine (2011, Figure 2), honesty was located close to the center of the multidimensional space defined by Schwartz's (2006) value dimensions. The intermediate character of the Integrity elements does not allow a clear prediction of cross-cultural differences in the salience of this cluster and its facets.

\section{Method}

The data for the current study were derived using semistructured interviews in a project aiming at exploring the indigenous concepts of personality in South Africa. The methods of data collection and analysis are described in detail in two previous publications (Nel et al., 2012; Valchev et al., 2011).

\section{Participants}

Interviews were conducted with 1,190 participants from the 11 language groups in their own language. A combination of quota and convenience sampling was used, obtaining variation in gender, urban/rural residence, education, and age. The sample included 1,027 Blacks (528 females; $M_{\text {Age }}=33.08$ years, $S D=11.12$ ), 58 Indians (39 females; $M_{\text {Age }}=30.11$ years, $S D=$ 10.26), and 105 Whites (44 Afrikaans and 61 English speakers; 67 females; $M_{\text {Age }}=32.21$ years, $S D=14.40)$.

\section{Instrument and Procedure}

Participants were asked to describe themselves and nine other persons they knew well: their best friend of the same sex, their best friend of the opposite sex, a parent, their eldest child or sibling, a grandparent, a colleague or friend from another ethnic group, a person who is the total opposite of the participant, a teacher they liked (if schooled, otherwise a person from the village whom they liked), and a teacher they disliked (if schooled, otherwise a person from the village whom they disliked). In part of the interviews (580 Blacks, 27 Indians, and 47 Whites), no self-descriptions and descriptions of a person opposite to oneself were obtained; descriptions of a neighbor and a disliked person were obtained instead. The following four prompts were used: "Please describe the following people to me by telling me what kind of person he or she is/was;" "Can you describe typical aspects of this person?"; "Can you describe the behavior or habits that are characteristic of this person?"; and "How would you describe this person to someone who does not know him/her?" All participants were asked these questions, and there was no limit to the number of descriptions provided per person. 
Data were collected by specially trained interviewers who were native speakers of the target language. The interviews were tape-recorded, transcribed, and translated into English by the interviewers. Language experts checked the accuracy of the translations and made corrections where necessary.

\section{Analysis and Quality Control}

In a preliminary stage, the purely evaluative terms, physical characteristics, life fact statements, and ambiguous terms were excluded. The total number of responses retained for the analysis was 47,598. Composite responses like "cheerful and sociable" were split and included separately in their respective categories. In the three main stages of the analysis, the responses were (a) labeled, providing common terms for trait descriptions and longer behavior descriptions (e.g., "He loves going out with friends" and "He was outgoing" were labeled as outgoing), (b) categorized into 188 facets combining synonyms and antonyms (e.g., outgoing and socializing in the Sociable facet), and (c) clustered, based on shared semantic content and patterns of cooccurrence, into 37 subclusters and nine clusters (e.g., the Communicative, Extravert/Introvert, Reserved, Shy, Sociable, Spontaneous, Story-Teller, and Talkative facets were included in the Sociability subcluster of the Extraversion cluster). Examples of utterances in the 188 facets can be found in Table 2 .

Each response was uniquely assigned to one of the 188 facets, implying respective assignment to one of the 37 subclusters and 9 clusters. The responses were coded primarily by the second author, with frequent consultations and discussions within the research team. A second rater coded a random set of 200 responses assigning them to facets; an interrater agreement of $86 \%$ was achieved. The cultural adequacy of the coding was ensured in several workshops with cultural experts on the studied cultures who provided feedback on the different levels of categorization. An independent personality expert was consulted in the final stages of the analysis, leading to final refinements of the model. The semantic interrelations between the 37 subclusters were examined in an independent study where we asked participants to rate how strongly each of the subclusters is related to all other subclusters. The outcomes suggested a similar structure to the nine clusters, although some of the social-relational clusters did not replicate in detail (Nel et al., 2012).

We analyzed the data using loglinear analysis on the frequency of responses categorized in facets, subclusters, and clusters (on loglinear analysis, or multiway frequency analysis, see Agresti, 2007; Tabachnick \& Fidell, 2007). Loglinear analysis assesses associations between categorical variables, where combinations of independent variables form cells in a table and the frequency in each cell is the dependent variable. A model with main effects only, or main effects and lower order interactions only, is tested against a model with (higher order) interactions. A significant goodness-of-fit statistic (likelihood ratio, LR, with a $\chi^{2}$ distribution) indicates significant difference between these two models and, hence, a significant effect of the (higher order) interactions. The specific sources of discrepancies can be identified using the standardized residuals; expressed as $z$ scores, they indicate how much the observed frequency of a cell deviates from the one predicted by the tested model. Absolute values above 2 are considered salient by common standards (Agresti, 2007).

\section{Results}

We tested the loglinear model with main effects of cluster and ethno-cultural group. ${ }^{3}$ The model's fit was poor, $\operatorname{LR}(16, n=47,598)=831.19, p<.001$, indicating a significant interaction. The proportions of responses per cluster and ethnocultural group are displayed in Table 1. 
Table I. Proportions (P), Standard Errors (SE), and Standardized Residuals (SR) of Personality Clusters per Ethnocultural Group

\begin{tabular}{|c|c|c|c|c|c|c|c|c|c|}
\hline \multirow[b]{3}{*}{ Cluster } & \multicolumn{9}{|c|}{ Ethnocultural Group } \\
\hline & \multicolumn{3}{|c|}{ Black } & \multicolumn{3}{|c|}{ Indian } & \multicolumn{3}{|c|}{ White } \\
\hline & $P$ & $S E$ & $S R$ & $P$ & SE & $S R$ & $P$ & $S E$ & $S R$ \\
\hline Conscientiousness & .09 & .002 & -0.84 & .08 & .006 & -0.96 & .10 & .006 & 2.73 \\
\hline Emotional Stability & .05 & .002 & -6.42 & .09 & .008 & 6.43 & .09 & .005 & $|0.9|$ \\
\hline Extraversion & .15 & .003 & -4.99 & .18 & .010 & 3.72 & .20 & .009 & 9.41 \\
\hline Facilitating & .06 & .002 & 5.08 & .05 & .005 & -0.87 & .02 & .002 & -|| $.7 \mid$ \\
\hline Integrity & .08 & .002 & -1.09 & .07 & .007 & -1.84 & .09 & .007 & 4.00 \\
\hline Intellect & .04 & .001 & -4.58 & .07 & .007 & $7.4 I$ & .06 & .005 & 5.72 \\
\hline Openness & .07 & .002 & 3.62 & .05 & .006 & -2.56 & .04 & .006 & -6.92 \\
\hline Relationship Harmony & .11 & .002 & 3.93 & .08 & .006 & -3.80 & .08 & .004 & -6.77 \\
\hline Soft-Heartedness & .36 & .004 & 2.92 & .32 & .014 & -2.99 & .31 & .012 & -4.90 \\
\hline
\end{tabular}

Note. Standardized residuals with an absolute value above 2 appear in bold typeface.

The standardized residuals suggested that Conscientiousness, Emotional Stability, Extraversion, Integrity, and Intellect were underrepresented in the Black group ( $S R$ s between -0.84 and -6.42) and overrepresented in the White group (SRs between 2.73 and 10.91). Facilitating, Openness, Relationship Harmony, and Soft-Heartedness, on the other hand, were overrepresented in the Black group (SRs between 2.92 and 5.08) and underrepresented in the White group (SRs between -4.90 and -11.71). The Indian group showed an intermediate pattern, although it had an extreme, low rather than intermediate, position in Conscientiousness $(S R=-0.96)$ and Integrity $(S R=-1.84)$ and high position in Intellect $(S R=7.41)$. The results were in line with expectations: The personal-growth clusters were more salient for Whites and the social-relational for Blacks. Openness clearly deviated from the prediction because it had the opposite pattern of that expected for the personal-growth clusters. Emotional Stability and Integrity, for which we did not specify expectations, were more salient for Whites than for Blacks.

To get an overall estimate of the extent to which the three groups differed in their use of the components of each cluster, we correlated the proportions of responses in facets per cluster (displayed in separate panels per cluster in Table 2) for pairs of groups. The average correlation was .66 for Blacks and Indians, .48 for Blacks and Whites, and .78 for Indians and Whites, with a grand average correlation of .64. These findings indicated that there was considerable agreement between the groups in the use of facets per cluster, but there were also noticeable differences, most pronounced between Blacks with Whites. This underscored the need to examine the differences in an analysis of the use of specific facets per cluster.

For each cluster separately, we tested the loglinear model with main effects of facets (and, separately, subclusters) and ethnocultural group. The fit tests of the loglinear models for all facets and subclusters were significant at $p<.001$, except for the models for the subclusters of Facilitating $(p<.01)$ and Integrity $(n s)$, indicating significant interactions. The proportions and standardized residuals can be found in Table 2. Given the large number of observed effects, it was deemed most instructive to examine the facets that displayed the opposite pattern of that predicted (or observed, in the case of Emotional Stability and Integrity, whose interaction with culture had not been predicted) for their overall cluster. In other words, the analysis focused on the facets overrepresented in the Black group and underrepresented in the White group for the 
Table 2. Proportions $(P)$ and Standardized Residuals $(S R)$ of Subclusters and Facets per Ethnocultural Group with Example Descriptions

\begin{tabular}{|c|c|c|c|c|c|c|c|}
\hline \multirow[b]{3}{*}{ Subclusters and Facets } & \multicolumn{6}{|c|}{ Ethnocultural Group } & \multirow[b]{3}{*}{ Example Descriptions } \\
\hline & \multicolumn{2}{|c|}{ Black } & \multicolumn{2}{|c|}{ Indian } & \multicolumn{2}{|c|}{ White } & \\
\hline & $P$ & $S R$ & $P$ & $S R$ & $P$ & $S R$ & \\
\hline \multicolumn{8}{|l|}{ I. Conscientiousness } \\
\hline $\begin{array}{l}\text { ACHIEVEMENT } \\
\text { ORIENTATION }\end{array}$ & .40 & 3.26 & .25 & -3.01 & .23 & -5.42 & \\
\hline Career-Oriented & .00 & -0.80 & .02 & 3.96 & .00 & -0.83 & $\begin{array}{l}\text { She prioritizes-a career before } \\
\text { serious relationship (English,W) }\end{array}$ \\
\hline Competitive & .00 & -0.67 & .00 & -0.30 & .01 & 1.73 & $\begin{array}{l}\text { Likes to compete and compare } \\
\text { herself with other people } \\
\text { (Xhosa) }\end{array}$ \\
\hline Dutiful & & -1.53 & & -0.45 & .00 & 3.80 & Dutiful (Afrikaans) \\
\hline Hard-Working & .38 & 3.94 & .23 & -3.30 & .18 & -6.79 & Hard-worker (Venda) \\
\hline $\begin{array}{l}\text { Performance- } \\
\text { Oriented }\end{array}$ & .00 & -1.33 & .00 & -0.61 & .02 & 3.45 & $\begin{array}{l}\text { He likes to achieve everything by } \\
\text { himself (N Sotho) }\end{array}$ \\
\hline Timeous & & -2.50 & & -0.73 & .01 & 6.20 & Timeous (Afrikaans) \\
\hline DEDICATION & .21 & -4.57 & .35 & 3.16 & .42 & 8.32 & \\
\hline Dedicated & .06 & -1.25 & .06 & -0.70 & .10 & 3.32 & Dedicated to his work (Tswana) \\
\hline Determined & .04 & -0.67 & .05 & 0.34 & .05 & 1.31 & $\begin{array}{l}\text { He is determined in everything he } \\
\text { does (S Sotho) }\end{array}$ \\
\hline Future-Oriented & .03 & -1.33 & .03 & 0.05 & .05 & 3.00 & $\begin{array}{l}\text { One who thinks about his future } \\
\text { (Swati) }\end{array}$ \\
\hline Passionate & .03 & 0.58 & .03 & 0.04 & .02 & -1.36 & $\begin{array}{l}\text { He does his work wholeheartedly } \\
\text { (Tsonga) }\end{array}$ \\
\hline Perseverant & .05 & -4.40 & .17 & 5.99 & .14 & 6.01 & She perseveres (Zulu) \\
\hline Purposeful & .00 & -4.35 & .02 & 0.63 & .06 & 9.51 & Goal-directed (English,W) \\
\hline ORDERLINESS & .27 & 0.74 & .28 & 0.39 & .22 & -1.94 & \\
\hline Consistent & .00 & -4.88 & .02 & 1.40 & .05 & 10.19 & Consistent (Afrikaans) \\
\hline Follow-up & .00 & 0.49 & & -0.52 & & -0.78 & $\begin{array}{l}\text { She likes to make follow-ups on } \\
\text { things (Ndebele) }\end{array}$ \\
\hline Meticulous & .03 & -1.97 & .09 & 4.19 & .05 & 1.68 & $\begin{array}{l}\text { Doesn't have room for mistakes } \\
\text { (Venda) }\end{array}$ \\
\hline Organized & .03 & -2.10 & .07 & 2.52 & .06 & 3.09 & $\mathrm{He}$ is a good planner (Tsonga) \\
\hline Punctual & .02 & -0.48 & .03 & 1.30 & .02 & 0.22 & $\begin{array}{l}\text { She is always late for her class ( } N \\
\text { Sotho) }\end{array}$ \\
\hline Tidy & .18 & 4.70 & .05 & -4.54 & .03 & -7.68 & Is always clean and tidy (Swati) \\
\hline Thorough & .00 & -1.89 & .03 & 5.25 & .01 & 0.79 & Very thorough (English, I,W) \\
\hline SELF-DISCIPLINE & .10 & 0.24 & .09 & -0.26 & .09 & -0.36 & \\
\hline Deliberating & .01 & -1.54 & .01 & -0.28 & .02 & 3.69 & $\begin{array}{l}\text { He does things without thinking } \\
\text { first (S Sotho) }\end{array}$ \\
\hline Disciplined & .01 & -1.45 & .01 & -0.03 & .03 & 3.33 & $\begin{array}{l}\text { He doesn't have self-discipline } \\
\text { (Tswana) }\end{array}$ \\
\hline Naughty & .02 & 0.17 & .03 & 1.51 & .01 & -1.39 & $\begin{array}{l}\text { He is very naughty and doesn't } \\
\text { listen (Zulu) }\end{array}$ \\
\hline Obedient & .05 & 3.05 & & -3.40 & .00 & -4.67 & Obeys his parents (Venda) \\
\hline Rebellious & .01 & -1.05 & .00 & -0.65 & .02 & 2.82 & $\begin{array}{l}\text { Rebel, dislikes any rules } \\
\text { (Afrikaans) }\end{array}$ \\
\hline
\end{tabular}


Table 2. (continued)

\begin{tabular}{|c|c|c|c|c|c|c|c|}
\hline \multirow[b]{3}{*}{ Subclusters and Facets } & \multicolumn{6}{|c|}{ Ethnocultural Group } & \multirow[b]{3}{*}{ Example Descriptions } \\
\hline & \multicolumn{2}{|c|}{ Black } & \multicolumn{2}{|c|}{ Indian } & \multicolumn{2}{|c|}{ White } & \\
\hline & $P$ & $S R$ & $P$ & $S R$ & $P$ & $S R$ & \\
\hline Serious & .01 & -1.66 & .04 & 5.05 & .01 & 0.40 & $\begin{array}{l}\text { Serious when time calls for you } \\
\text { to be serious (English, I) }\end{array}$ \\
\hline THOUGHTLESSNESS & .02 & -0.73 & .03 & 0.66 & .03 & 1.23 & \\
\hline Absent-Minded & .01 & -1.97 & .02 & 2.14 & .02 & 3.05 & Is forgetful (Xhosa) \\
\hline Reckless & .02 & 0.55 & .01 & -0.77 & .01 & -0.73 & He is careless (Swati) \\
\hline \multicolumn{8}{|c|}{ 2. Emotional Stability } \\
\hline BALANCE & .39 & 3.99 & .23 & -3.16 & .22 & -5.01 & \\
\hline Balancing Life & .00 & -2.18 & .01 & 1.58 & .01 & 2.83 & Balanced person (English,W) \\
\hline Even-Tempered & .08 & -0.72 & .09 & 0.65 & .09 & 0.85 & $\begin{array}{l}\text { Quite calm, not rattled easily } \\
\text { (English,W) }\end{array}$ \\
\hline Mature & .03 & -1.01 & .05 & 2.00 & .03 & 0.42 & $\begin{array}{l}\text { He behaves like a young boy } \\
\text { (Tsonga) }\end{array}$ \\
\hline Short-Tempered & .29 & 6.01 & .08 & -5.23 & .08 & $-7.2 I$ & She gets angry easily (Ndebele) \\
\hline COURAGE & .10 & -0.37 & .17 & 3.61 & .08 & -1.87 & \\
\hline Courageous & .06 & 2.99 & .02 & -2.27 & .01 & -3.82 & $\begin{array}{l}\text { Is brave and is able to kill a snake } \\
\text { alone (Swati) }\end{array}$ \\
\hline Fearful & .04 & -3.01 & .16 & 6.66 & .07 & 0.78 & She gets easily scared (Tswana) \\
\hline EGO STRENGTH & .17 & -1.19 & .15 & -1.28 & .24 & 3.05 & \\
\hline Attention-Seeking & .01 & -1.40 & .01 & -0.63 & .03 & 2.98 & Craves attention (Afrikaans) \\
\hline Demanding & .01 & -2.56 & .02 & 0.65 & .04 & 4.18 & Difficult to please (Xhosa) \\
\hline Needy & .03 & 0.68 & .02 & -0.93 & .02 & -0.58 & $\begin{array}{l}\text { He is always needy and expects } \\
\text { others to sympathize with him } \\
\text { (Tsonga) }\end{array}$ \\
\hline Self-Confident & .03 & -4.68 & .06 & 0.71 & .12 & 7.98 & Believed in himself (Zulu) \\
\hline Self-Respectful & .09 & $3.7 I$ & .04 & -2.13 & .01 & -5.23 & $\begin{array}{l}\text { Takes good care of herself } \\
\text { (Venda) }\end{array}$ \\
\hline $\begin{array}{l}\text { EMOTIONAL } \\
\text { CONTROL }\end{array}$ & .25 & 0.53 & .23 & -0.75 & .24 & -0.44 & \\
\hline Coping & .00 & -1.74 & .01 & 1.50 & .01 & 2.10 & Copes very well (English, I) \\
\hline $\begin{array}{l}\text { Obsessive- } \\
\text { Compulsive }\end{array}$ & & -1.66 & .01 & 2.46 & .00 & 1.27 & $\begin{array}{l}\text { Obsessive behavior like tea in the } \\
\text { morning then the pills } \\
\text { (English,W) }\end{array}$ \\
\hline Patient & .15 & -0.24 & .13 & -1.18 & .17 & 1.26 & She is a patient person (N Sotho) \\
\hline Temperamental & .10 & 1.67 & .09 & -0.25 & .06 & -2.85 & $\begin{array}{l}\text { One minute she is happy, the next } \\
\text { minute she is angry ( } \mathrm{N} \text { Sotho) }\end{array}$ \\
\hline $\begin{array}{l}\text { EMOTIONAL } \\
\text { SENSITIVITY }\end{array}$ & .06 & -5.32 & .17 & 4.60 & .17 & 6.40 & \\
\hline Emotional & .02 & -0.54 & .03 & $0.6 \mathrm{I}$ & .03 & 0.56 & Cries a lot (Tswana) \\
\hline Exaggerate & .00 & -1.83 & .00 & -0.85 & .02 & 3.92 & Overreacted (English,W) \\
\hline Sensitive & .03 & -5.59 & .14 & 5.61 & .12 & 6.18 & Easily gets hurt (Xhosa) \\
\hline NEUROTICISM & .03 & -1.84 & .04 & 0.97 & .05 & 2.66 & \\
\hline Complaining & .02 & -0.12 & .01 & -0.60 & .02 & 0.64 & $\begin{array}{l}\text { Real moaner. Moans about } \\
\text { everything (Afrikaans) }\end{array}$ \\
\hline
\end{tabular}


Table 2. (continued)

\begin{tabular}{|c|c|c|c|c|c|c|c|}
\hline \multirow[b]{3}{*}{ Subclusters and Facets } & \multicolumn{6}{|c|}{ Ethnocultural Group } & \multirow[b]{3}{*}{ Example Descriptions } \\
\hline & \multicolumn{2}{|c|}{ Black } & \multicolumn{2}{|c|}{ Indian } & \multicolumn{2}{|c|}{ White } & \\
\hline & $P$ & $S R$ & $P$ & $S R$ & $P$ & $S R$ & \\
\hline Content & .01 & -0.86 & .03 & 3.50 & .00 & -0.90 & She never gets satisfied ( $\mathrm{N}$ Sotho) \\
\hline Depressive & .00 & -2.24 & .00 & -0.03 & .01 & 4.09 & Depressed (Afrikaans) \\
\hline Neurotic & & -1.44 & & -0.56 & .00 & 3.00 & Neurotic (English,W) \\
\hline Tense & .00 & -1.28 & & -0.85 & .01 & 2.92 & $\begin{array}{l}\text { Gets stressed out over small } \\
\text { things (Xhosa) }\end{array}$ \\
\hline \multicolumn{8}{|l|}{ 3. Extraversion } \\
\hline DOMINANCE & .19 & 1.15 & .18 & -0.47 & .16 & -2.05 & \\
\hline Assertive & .02 & -2.94 & .06 & 5.38 & .03 & 2.35 & Stand for her viewpoint (Venda) \\
\hline Authoritarian & .04 & $-1.5 \mid$ & .05 & 0.55 & .06 & 2.74 & $\begin{array}{l}\text { He wanted things to be done his } \\
\text { way (S Sotho) }\end{array}$ \\
\hline Disciplining & .07 & 4.35 & .03 & -3.31 & .01 & -6.70 & $\begin{array}{l}\text { She liked to instill discipline } \\
\text { (Tsonga) }\end{array}$ \\
\hline Strict & .06 & 0.78 & .05 & -1.40 & .05 & -0.64 & Strict and bossy (Tswana) \\
\hline Captivating & .12 & -1.37 & .16 & 2.12 & .14 & 1.37 & $\begin{array}{l}\text { People just got drawn to her } \\
\text { (English,W) }\end{array}$ \\
\hline EXPRESSIVENESS & .01 & -7.23 & .07 & 6.90 & .07 & 10.15 & \\
\hline Emotional Sharing & .05 & 3.72 & .02 & -3.33 & .01 & -5.37 & $\begin{array}{l}\text { If something has upset him, he } \\
\text { tells me (Zulu) }\end{array}$ \\
\hline Noisy & .01 & -0.47 & .02 & 0.47 & .02 & 0.65 & A noisy person (S Sotho) \\
\hline Outspoken & .01 & -1.91 & .02 & 4.50 & .01 & 0.84 & $\begin{array}{l}\text { Outspoken, especially when } \\
\text { someone is wrong (Xhosa) }\end{array}$ \\
\hline Secretive & .02 & 2.33 & .00 & -2.33 & .00 & -3.19 & $\begin{array}{l}\text { He did not want to talk about his } \\
\text { past or future (Tsonga) }\end{array}$ \\
\hline Straightforward & .02 & -1.44 & .03 & 1.57 & .03 & 1.89 & $\begin{array}{l}\text { He is a straightforward and } \\
\text { straight talking person ( } \mathrm{N} \\
\text { Sotho) }\end{array}$ \\
\hline $\begin{array}{l}\text { POSITIVE } \\
\text { EMOTIONALITY }\end{array}$ & .24 & -2.33 & .31 & 2.84 & .29 & 2.85 & \\
\hline Cheerful & .10 & 1.92 & .11 & 1.38 & .05 & -4.91 & $\begin{array}{l}\text { Always in a jovial mood, is never } \\
\text { in a bad mood (Swati) }\end{array}$ \\
\hline Humorous & .09 & -2.62 & .10 & 0.16 & .14 & 5.29 & He is full of jokes (Ndebele) \\
\hline Optimistic & .00 & -4.67 & .04 & 6.90 & .03 & 4.86 & Very positive (Venda) \\
\hline Playful & .02 & 2.07 & .00 & -2.36 & .01 & -2.64 & A playful person (Tswana) \\
\hline Pleasure-Seeking & .01 & -1.29 & .02 & 3.69 & .01 & 0.12 & Likes to have fun (Xhosa) \\
\hline Vivacious & .02 & -3.86 & .03 & I.II & .06 & 7.19 & Energetic (Afrikaans) \\
\hline SOCIABILITY & .45 & 1.79 & .35 & -3.03 & .40 & -1.60 & \\
\hline Communicative & .02 & -0.25 & .01 & -0.64 & .02 & 0.95 & $\begin{array}{l}\text { I love communicating with people } \\
\text { (S Sotho) }\end{array}$ \\
\hline Extravert/Introvert & .01 & -6.37 & .04 & 2.00 & .09 & 11.77 & She is an introvert (Swati) \\
\hline Reserved & .02 & -0.76 & .03 & 1.37 & .02 & 0.63 & $\mathrm{He}$ is reserved (Zulu) \\
\hline Shy & .03 & 1.19 & .02 & -1.12 & .02 & -1.69 & $\begin{array}{l}\text { Shy, but if you get to know me, } \\
\text { you would understand me } \\
\text { (English, I) }\end{array}$ \\
\hline
\end{tabular}

(continued) 
Table 2. (continued)

\begin{tabular}{|c|c|c|c|c|c|c|c|}
\hline \multirow[b]{3}{*}{ Subclusters and Facets } & \multicolumn{6}{|c|}{ Ethnocultural Group } & \multirow[b]{3}{*}{ Example Descriptions } \\
\hline & \multicolumn{2}{|c|}{ Black } & \multicolumn{2}{|c|}{ Indian } & \multicolumn{2}{|c|}{ White } & \\
\hline & $P$ & $S R$ & $P$ & $S R$ & $P$ & $S R$ & \\
\hline Sociable & .16 & 1.05 & .16 & 0.00 & .13 & -2.16 & $\begin{array}{l}\text { He enjoys being with people ( } \mathrm{N} \\
\text { Sotho) }\end{array}$ \\
\hline Spontaneous & & -6.62 & .01 & 0.50 & .04 & 13.30 & Spontaneous (Afrikaans) \\
\hline Story-Teller & .02 & 2.54 & .01 & -1.45 & .00 & -4.24 & $\begin{array}{l}\text { She likes to tell about the times } \\
\text { when she was still a girl (Zulu) }\end{array}$ \\
\hline Talkative & .18 & 5.23 & .07 & -5.35 & .08 & -7.10 & $\begin{array}{l}\text { I like chatting with people } \\
\text { (Tsonga) }\end{array}$ \\
\hline \multicolumn{8}{|l|}{ 4. Facilitating } \\
\hline $\begin{array}{l}\text { ENCOURAGING } \\
\text { OTHERS }\end{array}$ & .36 & 0.90 & .26 & -2.02 & .27 & -1.44 & \\
\hline $\begin{array}{l}\text { Aspirations for } \\
\text { Others }\end{array}$ & .07 & 1.06 & .02 & -2.32 & .02 & -1.75 & $\begin{array}{l}\text { Wishes for everyone to succeed } \\
\text { (Xhosa) }\end{array}$ \\
\hline Encouraging & .28 & 1.09 & .20 & -1.64 & .15 & -2.67 & $\begin{array}{l}\text { Likes to encourage and motivate } \\
\text { people (Swati) }\end{array}$ \\
\hline Thought-Provoking & & -1.63 & & -0.45 & .02 & 7.33 & $\begin{array}{l}\text { Comes up with ideas }(. . .) \text { that } \\
\text { make you realize things (English, } \\
\text { W) }\end{array}$ \\
\hline Uplifting & .02 & -1.56 & .04 & 1.58 & .08 & 4.72 & $\begin{array}{l}\text { Brings out the lighter side in me } \\
\text { (English, I) }\end{array}$ \\
\hline GUIDANCE & .64 & -0.66 & .74 & 1.48 & .73 & 1.05 & \\
\hline Advising & .33 & 1.98 & .17 & -3.20 & .08 & -4.61 & Gives advice about life (Venda) \\
\hline Didactic & .13 & -1.02 & .27 & 4.45 & .11 & -0.86 & $\begin{array}{l}\text { He taught me so many things } \\
\text { (Ndebele) }\end{array}$ \\
\hline Guiding & .09 & 0.76 & .06 & -1.20 & .04 & -1.81 & $\begin{array}{l}\text { She is able to guide others } \\
\text { (Tsonga) }\end{array}$ \\
\hline Influential & .01 & -3.00 & .05 & 2.14 & .15 & 10.10 & A person that inspires (Tswana) \\
\hline Leading & .02 & -1.66 & .02 & 0.17 & .11 & 6.74 & $\begin{array}{l}\text { He is a leader at school and } \\
\text { in the community as well ( } \mathrm{N} \\
\text { Sotho) }\end{array}$ \\
\hline Respectable & .02 & -2.33 & .06 & 2.76 & .11 & 6.56 & $\begin{array}{l}\text { She is respected by people in the } \\
\text { village (S Sotho) }\end{array}$ \\
\hline Role Model & .04 & -1.86 & .11 & 3.87 & .11 & 3.33 & He is a role model to me (Zulu) \\
\hline \multicolumn{8}{|l|}{ 5. Integrity } \\
\hline FAIRNESS & .16 & 0.54 & .14 & -0.80 & .15 & -0.68 & \\
\hline Discriminative & .14 & 3.45 & .06 & -2.76 & .04 & -5.89 & $\begin{array}{l}\text { Discriminates, does not buy } \\
\text { clothes for everybody (Swati) }\end{array}$ \\
\hline Fair & .02 & -5.05 & .08 & 3.29 & .11 & 9.10 & Fair, not prejudiced (Afrikaans) \\
\hline INTEGRITY & .84 & -0.23 & .86 & 0.35 & .85 & 0.30 & \\
\hline Honest & .07 & -6.78 & .20 & 4.16 & .27 & 12.38 & Honest (Xhosa) \\
\hline Integrity & .00 & -2.87 & .03 & 5.70 & .01 & 2.74 & $\begin{array}{l}\text { Sound values and integrity } \\
(\text { English, W) }\end{array}$ \\
\hline Loyal & .01 & -5.53 & .07 & 3.33 & .11 & 10.15 & $\begin{array}{l}\text { Loyal-to duties and as friend } \\
\text { (English, I) }\end{array}$ \\
\hline
\end{tabular}

(continued) 
Table 2. (continued)

\begin{tabular}{|c|c|c|c|c|c|c|c|}
\hline \multirow[b]{3}{*}{ Subclusters and Facets } & \multicolumn{6}{|c|}{ Ethnocultural Group } & \multirow[b]{3}{*}{ Example Descriptions } \\
\hline & \multicolumn{2}{|c|}{ Black } & \multicolumn{2}{|c|}{ Indian } & \multicolumn{2}{|c|}{ White } & \\
\hline & $P$ & $S R$ & $P$ & $S R$ & $P$ & $S R$ & \\
\hline Morally Conscious & .15 & 1.60 & .13 & -0.10 & .08 & -3.48 & $\begin{array}{l}\text { He does not like people to do } \\
\text { bad things (N Sotho) }\end{array}$ \\
\hline Pretending & .05 & 0.85 & .02 & -1.93 & .04 & -0.67 & $\begin{array}{l}\text { A person who pretends to like } \\
\text { you whereas he does not (Zulu) }\end{array}$ \\
\hline Responsible & .12 & 2.28 & .05 & -2.31 & .06 & -3.59 & He never abandoned me (Zulu) \\
\hline Trustworthy & .26 & 0.59 & .30 & 1.37 & .21 & -2.18 & Reliable and trustworthy (Venda) \\
\hline Truthful & .19 & 3.46 & .06 & -3.76 & .07 & -5.28 & $\begin{array}{l}\text { She likes telling the truth } \\
\text { (Ndebele) }\end{array}$ \\
\hline \multicolumn{8}{|l|}{ 6. Intellect } \\
\hline AESTHETICS & .16 & 2.33 & .08 & $-2.4 I$ & .09 & -2.69 & \\
\hline Artistic & .00 & -2.30 & .02 & 2.61 & .02 & 2.48 & $\begin{array}{l}\text { Artistic and creative with lots of } \\
\text { interests (Afrikaans) }\end{array}$ \\
\hline Concrete Work & .11 & 4.08 & .01 & -3.79 & .01 & -5.07 & He loved handiwork (Tsonga) \\
\hline Creative & .03 & -1.14 & .04 & 0.54 & .05 & 1.84 & $\begin{array}{l}\text { Creative, makes furniture } \\
\text { (English, I) }\end{array}$ \\
\hline Musical & .01 & 0.80 & & -1.12 & .00 & -0.69 & She is a good singer (Swati) \\
\hline Talented & .01 & 0.76 & .00 & -0.85 & .01 & -0.84 & He has many talents (Tswana) \\
\hline REASONING & .20 & -6.19 & .43 & 4.19 & .53 & 8.94 & \\
\hline Intelligent & .15 & -4.61 & .27 & 2.31 & .37 & 7.30 & $\begin{array}{l}\text { Is able to see where the problem } \\
\text { lies (Xhosa) }\end{array}$ \\
\hline Knowledgeable & .04 & -2.58 & .08 & 2.18 & .09 & 3.37 & $\begin{array}{l}\text { He understands or knows history } \\
\text { well, and wild animals (Ndebele) }\end{array}$ \\
\hline Logical & .01 & -4.21 & .07 & 4.43 & .07 & 4.83 & Rational and logical (English, I) \\
\hline Self-Insight & .01 & 0.52 & .00 & -0.31 & .00 & -0.79 & He understands himself (S Sotho) \\
\hline SKILLFULNESS & .33 & 3.02 & .21 & -2.33 & .18 & -4.14 & \\
\hline Articulate & .09 & 0.53 & .08 & -0.47 & .08 & -0.68 & $\begin{array}{l}\text { He taught history nicely and } \\
\text { explained beautifully (Zulu) }\end{array}$ \\
\hline Competent & .19 & 2.63 & .13 & -1.58 & .08 & -3.96 & He does his work well (Tswana) \\
\hline Enterprising & .04 & 2.12 & .00 & -2.52 & .01 & -2.21 & $\begin{array}{l}\text { It is a person who owns and runs } \\
\text { his shop very well (Zulu) }\end{array}$ \\
\hline Useless & .00 & 0.35 & & -0.34 & & -0.42 & $\mathrm{He}$ is useless (Tsonga) \\
\hline SOCIAL INTELLECT & .31 & 1.53 & .28 & -0.17 & .21 & -2.89 & \\
\hline Perceptive & .03 & -1.08 & .04 & -0.19 & .06 & 2.29 & $\begin{array}{l}\text { She could easily see when you } \\
\text { had a problem (Zulu) }\end{array}$ \\
\hline Socially Intelligent & .01 & -1.07 & .02 & 0.45 & .02 & 1.77 & $\begin{array}{l}\text { Knows how to deal with people } \\
\text { (Xhosa) }\end{array}$ \\
\hline Understanding & .27 & 2.37 & .23 & -0.22 & .13 & -4.53 & $\begin{array}{l}\text { He understands my traditions } \\
\text { (Venda) }\end{array}$ \\
\hline \multicolumn{8}{|l|}{ 7. Openness } \\
\hline $\begin{array}{l}\text { BROAD- } \\
\text { MINDEDNESS }\end{array}$ & .71 & 0.38 & .77 & 1.01 & .61 & -1.98 & \\
\hline Dreamer & .00 & 0.12 & & -0.73 & .00 & 0.22 & Dreamer (Xhosa) \\
\hline
\end{tabular}


Table 2. (continued)

\begin{tabular}{|c|c|c|c|c|c|c|c|}
\hline \multirow[b]{3}{*}{ Subclusters and Facets } & \multicolumn{6}{|c|}{ Ethnocultural Group } & \multirow[b]{3}{*}{ Example Descriptions } \\
\hline & \multicolumn{2}{|c|}{ Black } & \multicolumn{2}{|c|}{ Indian } & \multicolumn{2}{|c|}{ White } & \\
\hline & $P$ & $S R$ & $P$ & $S R$ & $P$ & $S R$ & \\
\hline Independent & .05 & -2.30 & .07 & 0.64 & .16 & 6.58 & $\begin{array}{l}\text { I am an independent-minded } \\
\text { person (S Sotho) }\end{array}$ \\
\hline Individualistic & .00 & -3.40 & .06 & 8.50 & .03 & 3.60 & Individualistic (Afrikaans) \\
\hline Open-Minded & .03 & -3.38 & .15 & 6.77 & .11 & 4.95 & $\begin{array}{l}\text { He is interested in other } \\
\text { languages as well (N Sotho) }\end{array}$ \\
\hline Prim and Proper & & -2.06 & .01 & 1.29 & .01 & 5.33 & Prim and proper (English, I,W) \\
\hline Progressive & .02 & -3.81 & .15 & 7.52 & .11 & 5.66 & Conservative (Afrikaans) \\
\hline Religious & .45 & 2.91 & .27 & -2.98 & .16 & -6.57 & I'm a religious person (Tsonga) \\
\hline Traditional & .15 & 2.25 & .07 & -2.52 & .03 & -4.91 & Liked traditional things (Swati) \\
\hline Visionary & .01 & -0.09 & & -1.03 & .01 & I.II & Visionary (Xhosa) \\
\hline $\begin{array}{l}\text { EPISTEMIC } \\
\text { CURIOSITY }\end{array}$ & .16 & 0.13 & .11 & -1.62 & .18 & 0.91 & \\
\hline $\begin{array}{l}\text { Academically } \\
\text { Oriented }\end{array}$ & .05 & -0.15 & .04 & -0.52 & .06 & 0.89 & $\begin{array}{l}\text { She likes to be educated } \\
\text { (Ndebele) }\end{array}$ \\
\hline Eager to Learn & .07 & 1.59 & .03 & -2.00 & .01 & -3.28 & $\begin{array}{l}\text { Likes to learn about other } \\
\text { people's culture (Venda) }\end{array}$ \\
\hline Inquisitive & .04 & $-1.5 \mid$ & .04 & -0.08 & .11 & 4.73 & $\begin{array}{l}\text { A person that likes to know the } \\
\text { answers of life (Tswana) }\end{array}$ \\
\hline MATERIALISM & .10 & 0.25 & .08 & -0.88 & .10 & -0.05 & \\
\hline Fashion-Conscious & .08 & 0.60 & .05 & -1.12 & .06 & -0.94 & $\begin{array}{l}\text { Is always well-dressed in current } \\
\text { fashion (Swati) }\end{array}$ \\
\hline Materialistic & .02 & -0.55 & .03 & 0.18 & .04 & 1.54 & Likes money (Zulu) \\
\hline $\begin{array}{l}\text { OPENNESS TO } \\
\text { EXPERIENCE }\end{array}$ & .02 & -2.48 & .04 & 0.42 & .11 & 7.34 & \\
\hline Adventurous & & -5.22 & .02 & 1.53 & .10 & $|4.9|$ & Adventurous (English, I,W) \\
\hline Like to Travel & .02 & 0.55 & .02 & -0.54 & .01 & -1.27 & She likes travelling (S Sotho) \\
\hline \multicolumn{8}{|c|}{ 8. Relationship Harmony } \\
\hline APPROACHABILITY & .32 & -5.19 & .62 & 7.11 & .63 & 9.72 & \\
\hline Accommodating & .01 & 0.01 & .00 & -0.40 & .01 & 0.26 & $\begin{array}{l}\text { Addressed us in English so we } \\
\text { could understand (Xhosa) }\end{array}$ \\
\hline Approachable & .06 & -4.93 & .22 & 8.33 & .18 & 8.05 & $\begin{array}{l}\text { She is approachable, I could speak } \\
\text { to her about anything (S Sotho) }\end{array}$ \\
\hline Arrogant & .07 & -2.63 & .14 & 3.90 & .14 & 4.72 & $\begin{array}{l}\text { He thinks he is better than all the } \\
\text { other people (N Sotho) }\end{array}$ \\
\hline Flexible & .01 & -3.55 & .06 & 4.64 & .06 & 6.83 & Flexible to situation (Tswana) \\
\hline Humble & .05 & 0.13 & .05 & 0.32 & .04 & -0.62 & $\begin{array}{l}\text { She is a humble and down-to- } \\
\text { earth person (Ndebele) }\end{array}$ \\
\hline Open for Others & .02 & -0.65 & .02 & 0.64 & .02 & 1.39 & $\begin{array}{l}\text { Accepts people for who and what } \\
\text { they are (English,W) }\end{array}$ \\
\hline Proud & .03 & 0.35 & .05 & 2.20 & .01 & -2.67 & $\begin{array}{l}\text { Is proud and thinks of herself } \\
\text { better than others (Swati) }\end{array}$ \\
\hline Stubborn & .06 & -2.08 & .05 & -1.24 & .16 & 7.01 & $\begin{array}{l}\text { Was stubborn, did not listen to } \\
\text { anybody (Tswana) }\end{array}$ \\
\hline
\end{tabular}


Table 2. (continued)

\begin{tabular}{|c|c|c|c|c|c|c|c|}
\hline \multirow[b]{3}{*}{ Subclusters and Facets } & \multicolumn{6}{|c|}{ Ethnocultural Group } & \multirow[b]{3}{*}{ Example Descriptions } \\
\hline & \multicolumn{2}{|c|}{ Black } & \multicolumn{2}{|c|}{ Indian } & \multicolumn{2}{|c|}{ White } & \\
\hline & $P$ & $S R$ & $P$ & $S R$ & $P$ & $S R$ & \\
\hline Tolerant & .01 & -1.43 & .02 & 3.63 & .01 & 1.43 & Tolerant (Afrikaans) \\
\hline Welcoming & .02 & 0.99 & .01 & $-|.3|$ & .01 & -1.90 & Welcoming - to everyone (Venda) \\
\hline CONFLICT-SEEKING & .08 & 0.40 & .07 & -0.66 & .07 & -0.68 & \\
\hline Argumentative & .02 & 0.93 & .00 & -1.82 & .01 & -1.32 & Likes to quarrel (Xhosa) \\
\hline Provoking & .01 & 1.12 & & -1.77 & .00 & -1.91 & $\begin{array}{l}\text { Provocative and calls people } \\
\text { names (Swati) }\end{array}$ \\
\hline Troublesome & .05 & -0.55 & .07 & 1.07 & .06 & 0.80 & $\begin{array}{l}\text { Creates tension for nothing } \\
\text { (Zulu) }\end{array}$ \\
\hline $\begin{array}{l}\text { INTERPERSONAL } \\
\text { RELATEDNESS }\end{array}$ & .44 & 2.91 & .28 & -3.62 & .25 & -5.74 & \\
\hline Appeasing & .01 & 0.41 & & -1.37 & .01 & -0.15 & $\begin{array}{l}\text { If she made you angry she will } \\
\text { come to your house and } \\
\text { apologize (N Sotho) }\end{array}$ \\
\hline Constructive & .01 & 0.89 & .00 & -0.82 & & -1.97 & Shares constructive ideas (Xhosa) \\
\hline Cooperative & .03 & 1.19 & & -2.64 & .01 & -1.47 & Works well with others (Tswana) \\
\hline Forgiving & .03 & 0.32 & .04 & 0.66 & .02 & -1.44 & She holds no grudges (Tsonga) \\
\hline $\begin{array}{l}\text { Good Relations } \\
\text { with Another }\end{array}$ & .12 & 2.35 & .05 & -3.12 & .04 & -4.48 & $\begin{array}{l}\text { Maintains a good relation with } \\
\text { others (Venda) }\end{array}$ \\
\hline Peaceful & .10 & 2.02 & .02 & -3.88 & .05 & -2.95 & $\begin{array}{l}\text { He likes peace amongst people } \\
\text { (N Sotho) }\end{array}$ \\
\hline Peacekeeping & .02 & -1.21 & .05 & 3.23 & .03 & 1.07 & $\begin{array}{l}\text { He likes to bring peace where } \\
\text { there is misunderstanding } \\
\text { (Ndebele) }\end{array}$ \\
\hline Well-Mannered & .13 & 0.90 & .12 & -0.38 & .09 & -2.35 & Doesn't ask nicely (Afrikaans) \\
\hline MEDDLESOMENESS & .15 & 3.13 & .03 & -4.87 & .04 & -5.44 & \\
\hline Gossiping & .13 & 3.25 & .01 & -4.82 & .02 & $-5.8 I$ & $\begin{array}{l}\text { A person who spreads rumors } \\
\text { about other people (S Sotho) }\end{array}$ \\
\hline Interfering & .03 & 0.48 & .01 & -1.22 & .02 & -0.48 & $\begin{array}{l}\text { Likes to interfere in other } \\
\text { people's business (English,W) }\end{array}$ \\
\hline \multicolumn{8}{|l|}{ 9. Soft-Heartedness } \\
\hline ACTIVE SUPPORT & .14 & -2.80 & .22 & 5.44 & .18 & 3.26 & \\
\hline $\begin{array}{l}\text { Community } \\
\text { Involvement }\end{array}$ & .00 & 0.95 & .00 & -0.64 & .00 & -1.99 & $\begin{array}{l}\text { There is one person who } \\
\text { is always looking after the } \\
\text { community (Zulu) }\end{array}$ \\
\hline Heedful & .01 & -2.11 & .03 & 2.59 & .03 & 3.59 & $\begin{array}{l}\text { She listens when you talk to her } \\
\text { (S Sotho) }\end{array}$ \\
\hline Helpful & .09 & -0.98 & .12 & 2.60 & .10 & 0.63 & $\begin{array}{l}\text { Is helpful when you are in need } \\
\text { (Swati) }\end{array}$ \\
\hline Protective & .00 & -1.74 & .00 & 1.36 & .01 & 3.52 & Protective (Xhosa) \\
\hline $\begin{array}{l}\text { Solving Problems of } \\
\text { Others }\end{array}$ & .01 & 1.49 & .00 & -2.24 & .00 & -2.22 & $\begin{array}{l}\text { If I have a problem, she knows } \\
\text { how to solve it (Ndebele) }\end{array}$ \\
\hline Supportive & .03 & -3.48 & .07 & 6.58 & .05 & 4.19 & $\begin{array}{l}\text { I like to give people my support } \\
\text { (Tswana) }\end{array}$ \\
\hline
\end{tabular}


Table 2. (continued)

\begin{tabular}{|c|c|c|c|c|c|c|c|}
\hline \multirow[b]{3}{*}{ Subclusters and Facets } & \multicolumn{6}{|c|}{ Ethnocultural Group } & \multirow[b]{3}{*}{ Example Descriptions } \\
\hline & \multicolumn{2}{|c|}{ Black } & \multicolumn{2}{|c|}{ Indian } & \multicolumn{2}{|c|}{ White } & \\
\hline & $P$ & $S R$ & $P$ & $S R$ & $P$ & $S R$ & \\
\hline AMIABILITY & .12 & -7.43 & .21 & 5.21 & .28 & 15.47 & \\
\hline Friendly & .03 & -8.34 & .06 & 2.56 & .13 & 19.78 & She is a friendly person (Tsonga) \\
\hline Irritating & .00 & -1.53 & .01 & 3.26 & .01 & 1.58 & $\begin{array}{l}\text { He is annoying and irritating ( } \mathrm{S} \\
\text { Sotho) }\end{array}$ \\
\hline Kind & .07 & -1.42 & .10 & 2.37 & .09 & 1.95 & Kind (Venda) \\
\hline Likeable & .01 & $-3.4 I$ & .02 & 3.54 & .02 & 6.24 & $\mathrm{He}$ is loved by everyone (S Sotho) \\
\hline Pleasant & .01 & -2.49 & .02 & 1.99 & .02 & 5.01 & $\begin{array}{l}\text { He was a nice person to live with } \\
\text { (Zulu) }\end{array}$ \\
\hline Stern & .00 & -1.13 & .00 & 0.58 & .00 & $2.5 I$ & $\begin{array}{l}\text { Always serious, not smiling } \\
\text { (Xhosa) }\end{array}$ \\
\hline EGOISM & .13 & 1.08 & .12 & -0.77 & .11 & -2.23 & \\
\hline Generous & .08 & 1.98 & .06 & -2.27 & .06 & -3.46 & $\begin{array}{l}\text { One who is generous and gives } \\
\text { food when asked (Swati) }\end{array}$ \\
\hline Greedy & .00 & 0.08 & & -1.38 & .00 & 0.80 & Greedy (Afrikaans) \\
\hline Jealous & .02 & 2.56 & .01 & -2.62 & .01 & -4.72 & $\begin{array}{l}\text { A person who is jealous of other } \\
\text { people's possessions (Zulu) }\end{array}$ \\
\hline Self-Centered & .00 & -2.34 & .00 & 0.17 & .01 & 5.96 & $\begin{array}{l}\text { All revolves around her, she } \\
\text { thinks (English, I) }\end{array}$ \\
\hline Selfish & .02 & -2.55 & .05 & 5.18 & .03 & $2.8 I$ & $\begin{array}{l}\text { Wants everything for himself } \\
\text { (Xhosa) }\end{array}$ \\
\hline EMPATHY & .40 & 3.17 & .31 & -3.66 & .31 & -5.53 & \\
\hline Agreeing & .00 & -0.63 & .00 & 1.03 & .00 & 0.88 & Agreeable (Tswana) \\
\hline Caring & .10 & -1.43 & .13 & 2.73 & .11 & 1.72 & $\begin{array}{l}\text { Cares about other people } \\
\text { (English,W) }\end{array}$ \\
\hline Compassionate & .03 & 3.16 & .01 & -3.07 & .01 & -5.93 & $\begin{array}{l}\text { She feels pity for you when you } \\
\text { are in trouble (N Sotho) }\end{array}$ \\
\hline Considerate & .01 & -3.75 & .02 & 3.58 & .03 & 7.12 & $\begin{array}{l}\text { Considers others' feelings } \\
\text { (Afrikaans) }\end{array}$ \\
\hline Humane & .00 & 0.95 & & -1.77 & .00 & -1.16 & $\begin{array}{l}\text { He is good-natured and shows } \\
\text { humanity (Swati) }\end{array}$ \\
\hline Loving & .18 & 2.37 & .13 & -3.21 & .14 & -3.80 & $\begin{array}{l}\text { Loving and caring-concerned } \\
\text { about my life (Venda) }\end{array}$ \\
\hline Respectful & .08 & 4.92 & .02 & -6.42 & .02 & -8.06 & $\begin{array}{l}\text { He respects other people } \\
\text { (Tsonga) }\end{array}$ \\
\hline Satisfying Others & .00 & 0.14 & .00 & 1.58 & & $-1.5 \mid$ & $\begin{array}{l}\text { Makes people happy all the time } \\
\text { (Xhosa) }\end{array}$ \\
\hline GRATEFULNESS & .01 & 0.51 & .01 & 1.42 & .01 & -2.36 & \\
\hline Appreciative & .01 & 1.33 & .01 & -0.28 & .00 & -3.26 & $\begin{array}{l}\text { She doesn't appreciate the good } \\
\text { of other people (Ndebele) }\end{array}$ \\
\hline Grateful & .00 & -1.09 & $.0 \mathrm{I}$ & 2.98 & .00 & 0.63 & $\begin{array}{l}\text { He is not thankful for what } \\
\text { people do for him (N Sotho) }\end{array}$ \\
\hline HOSTILITY & .19 & 3.70 & .13 & -4.12 & .12 & -6.58 & \\
\hline
\end{tabular}


Table 2. (continued)

\begin{tabular}{|c|c|c|c|c|c|c|c|}
\hline \multirow[b]{3}{*}{ Subclusters and Facets } & \multicolumn{6}{|c|}{ Ethnocultural Group } & \multirow[b]{3}{*}{ Example Descriptions } \\
\hline & \multicolumn{2}{|c|}{ Black } & \multicolumn{2}{|c|}{ Indian } & \multicolumn{2}{|c|}{ White } & \\
\hline & $P$ & $S R$ & $P$ & $S R$ & $P$ & $S R$ & \\
\hline Abusive & .02 & 2.29 & .01 & -2.57 & .00 & -4.05 & $\begin{array}{l}\text { Abusive-physically and } \\
\text { emotionally (English,W) }\end{array}$ \\
\hline Aggressive & .04 & 3.40 & .01 & -3.91 & .01 & -5.96 & $\begin{array}{l}\text { He is aggressive and likes fighting } \\
\text { (Tswana) }\end{array}$ \\
\hline Critical & .01 & -2.76 & .01 & 0.82 & .02 & 6.58 & $\begin{array}{l}\text { He likes criticizing others } \\
\text { (Tsonga) }\end{array}$ \\
\hline Cruel & .03 & 2.13 & .01 & -3.33 & .02 & -3.09 & $\mathrm{He}$ is a cruel person (S Sotho) \\
\hline Delinquent & .03 & 3.28 & .00 & -4.44 & .01 & -5.25 & Mugged people (Xhosa) \\
\hline Denigrating & .02 & -0.61 & .04 & 3.51 & .02 & -0.99 & Likes to belittle others (Venda) \\
\hline Distrustful & .00 & -2.95 & .01 & 2.11 & .02 & 6.11 & He mistrusts people (English,W) \\
\hline Exploiting & .00 & 0.04 & .01 & 0.43 & .00 & -0.42 & Uses other people (Afrikaans) \\
\hline Intimidating & .00 & -1.16 & .01 & 3.38 & .00 & 0.53 & $\begin{array}{l}\text { People were afraid of him (N } \\
\text { Sotho) }\end{array}$ \\
\hline Verbally Aggressive & .03 & 2.14 & .02 & -2.07 & .01 & -4.03 & Swears at his parents (Zulu) \\
\hline Wrathful & .00 & 0.68 & & -0.85 & & -1.15 & $\begin{array}{l}\text { Is wrathful and scolds, especially } \\
\text { when you have disappointed her } \\
\text { (Swati) }\end{array}$ \\
\hline
\end{tabular}

Note. $\mathrm{N}$ Sotho $=$ Northern Sotho; $\mathrm{S}$ Sotho $=$ Southern Sotho. For the responses of English speakers, ethnic group (Indian or White) is indicated by initial letter. Subclusters are presented in small caps and facets are presented alphabetically per subcluster. The analyses were done separately for subclusters and facets per cluster. Standardized residuals with an absolute value above 2 appear in bold typeface. Standardized residuals of subclusters and facets with a pattern opposite to that predicted for their cluster (or opposite to the observed pattern, for Emotional Stability and Integrity) are italicized. The examples are adapted from Nel et al.'s (20I2) Table 2.

personal-growth clusters (as well as Emotional Stability and Integrity), and on those underrepresented in the Black group and overrepresented in the White group for the social-relational clusters. There were 48 such facets in total, presented in the following paragraphs.

Personal-Growth Clusters. In the personal-growth clusters, the following 18 facets were overrepresented in Blacks ( $S R$ s between 1.05 and 5.23) and underrepresented in Whites ( $S R$ s between -2.16 and -7.68) with Indians generally in between ( $S R$ s between -5.35 and 1.38; see Table 2): Hard-Working, Tidy, and Obedient (in Conscientiousness), Disciplining, Emotional Sharing, Secretive, Cheerful, Playful, Sociable, Story-Teller, and Talkative (in Extraversion), Concrete Work, Competent, Enterprising, and Understanding (in Intellect), and Religious, Traditional, and Eager to Learn (in Openness).

Several patterns could be distinguished in these findings. First, across clusters, facets associated with preservation of traditional order (like Obedient and Traditional) were particularly salient among Blacks. This pattern was in line with our expectation for Conscientiousness facets, but affected Openness too. Second, some facets that have to do with personal development (like Hard-Working and Eager to Learn) were also pronounced in the Black group, possibly pointing to an increased salience of present-day opportunities for individual socio-economic advancement. Third, in Extraversion, facets defining qualitative and quantitative aspects of 
communication (like Emotional Sharing and Talkative) seemed to be most salient for Blacks, and relatively more so than facets of positive affect and enthusiasm. Fourth, we found the expected distinction between conventional concepts of intelligence and openness (like Knowledgeable and Inquisitive), which were more salient for Whites, and concepts involving practical and social aspects of intelligence (like Competent and Understanding, the latter used almost exclusively in interpersonal sense), which were more salient for Blacks. Finally, across the clusters, facets that represent concrete manifestations of underlying traits were more salient for Blacks than facets with closely related but more abstract meaning (e.g., Hard-Working vs. Performance-Oriented, Talkative vs. Communicative, Concrete Work vs. Creative, and Like to Travel vs. Adventurous).

Social-Relational Clusters. The following 22 facets were underrepresented in Blacks in the social-relational clusters: Thought-Provoking, Uplifting, Influential, Leading, Respectable, and Role Model (in Facilitating), Approachable, Arrogant, Flexible, and Stubborn (in Relationship Harmony), and Heedful, Protective, Supportive, Friendly, Likeable, Pleasant, Stern, Self-Centered, Selfish, Considerate, Critical, and Distrustful (in Soft-Heartedness). All listed facets were underrepresented in Blacks (SRs between -1.13 and -8.34) and overrepresented in Whites (SRs between 2.51 and 19.78). Indians generally were between the two groups with $S R$ s between -1.24 and 8.33, although they had the highest representation in four of these facets (see Table 2).

The following patterns were distinguished. First, in the Facilitating cluster, the facets focusing more on the qualities of the individual as a guide (like Leading and Respectable) were more prominent in Whites, whereas facets referring to the beneficial aspects of guidance for others (like Encouraging and Advising) were more prominent in Blacks. Second, the facets of Relationship Harmony and Soft-Heartedness that were most overrepresented in Whites as well as Indians were often among the classic Big-Five Agreeableness elements (like Approachable, Flexible, Friendly, Considerate, and Distrustful). The facets that were more salient for Blacks were found in the Empathy subcluster (where the Respectful facet suggested the salience of relationship norms in a hierarchical relationship context), in the relatively more culture-specific subclusters (Interpersonal Relatedness, Meddlesomeness, and Gratefulness), and in the domain of disruptive behaviors (notably in the Hostility subcluster; see Table 2). The overall pattern suggested an increased salience of preservation of relationship norms for Blacks.

Emotional Stability and Integrity. Both the Emotional Stability and the Integrity cluster were underrepresented in Blacks and overrepresented in Whites, and it is hence interesting to examine the facets that displayed a pattern in the opposite direction. In Emotional Stability, the ShortTempered, Courageous, Self-Respectful, and Temperamental facets were overrepresented in Blacks (SRs between 1.67 and 6.01) and underrepresented in Whites (SRs between -2.85 and -7.21 ), with intermediate results in Indians ( $S R$ s between -0.25 and -5.23 ; see Table 2). The results indicated the expected distinction between internalizing and externalizing elements of Emotional Stability. The internalizing elements (most facets of this cluster, especially those under the Emotional Sensitivity and Neuroticism subclusters) were more prominent in Whites, and the externalizing elements (Short-Tempered and Temperamental) in Blacks. The Courageous and Self-Respectful facets were an interesting exception as they were especially salient in the Black group.

In Integrity, the Discriminative, Morally Conscious, Responsible, and Truthful facets were overrepresented in Blacks (SRs between 1.60 and 3.46) and underrepresented in Whites (SRs between -3.48 and -5.89 ), with Indians displaying an intermediate pattern ( $S R \mathrm{~s}$ between -0.10 and -3.76; see Table 2). The Discriminative facet arguably pointed to the increased salience of social discrimination in the groups most affected by it. The other three facets appeared to indicate the salience of diverse moral norms, often expressed in terms of concrete, norm-breaching behaviors (such as acts of irresponsibility). The facets overrepresented in Blacks referred to 
fairly concrete behaviors, whereas the facets overrepresented in Whites (such as Honest and Loyal) referred to more abstract concepts.

\section{Discussion}

The present study, employing an emic-etic approach, investigated cross-cultural differences in the salience of the components of an indigenous model of personality in three ethnocultural groups in South Africa: Blacks, Indians, and Whites. We found a moderate overall agreement on the components of the model across groups, but also substantial differences in the use both of broad personality clusters and of their specific components.

\section{Broad Cluster Preferences}

On the level of clusters, we made a distinction between those focusing more on personal growth (Conscientiousness, Extraversion, Intellect, and Openness) and those focusing more on the quality of social-relational functioning (Facilitating, Relationship Harmony, and Soft-Heartedness). Consistent with predictions from the individualism-collectivism framework, participants from the more collectivistic Black group made the fewest references to the personal-growth clusters, and participants from the more individualistic White group the most, with Indians generally in the middle; the reverse was true for the social-relational clusters. This finding is in line with research showing that agentic self-concepts (more strongly represented in personal-growth clusters) are more salient in individualistic cultures and communal self-concepts (more strongly represented in social-relational clusters) in collectivistic cultures (Del Prado et al., 2007; Sedikides et al., 2003). Our study suggests that cultural differences in the salience of agency and communion concepts affect not only self-concepts but also personality.

A notable exception to this pattern was the Openness cluster, which was overrepresented in Blacks and underrepresented in Whites. Inspection of the lower-level components of Openness identified two somewhat atypical facets that appeared to be causing this effect: Religious and Traditional. Research has suggested that different aspects of religion are associated with Agreeableness, Conscientiousness, and Openness (Saroglou, 2010), and our conceptual categorization, based on content analysis and not yet supported by quantitative data, may have overemphasized aspects of spirituality. Similarly, a case could be made for the Traditional facet as related to low Openness or to high Conscientiousness (e.g., Roccas et al., 2002). In an additional analysis we moved the Religious and Traditional facets to Conscientiousness and re-ran the loglinear analysis on clusters. Openness now displayed the expected pattern of overrepresentation in Whites $(S R=2.65)$ and underrepresentation in Blacks $(S R=-1.73)$; the pattern was reversed for Conscientiousness $\left(S R_{\text {Whites }}=-4.03, S R_{\text {Blacks }}=2.77\right)$. In conclusion, after the removal of the two more ambivalent facets, Openness also confirmed the expectations for personal-growth clusters.

Emotional Stability and Integrity, although not predicted, were found to be overrepresented in Whites' descriptions and underrepresented in Blacks'. It could be argued that the two clusters address attention primarily to intrapsychic characteristics and are hence person-focused, but that would only be true for some of their facets. Emotional Stability is one of the personality factors that have had less than perfect replication in psycholexical studies, and it has been suggested that its importance may have been overemphasized in (Western) personality psychology (De Raad et al., 2010). Integrity, in turn, is a recently introduced personality construct and its theoretical and empirical links to personal values across groups still need to be established. At present, it seems fair to conclude that the two clusters represent concepts that are more salient in Whites than in Blacks. 


\section{Common Patterns of Differences in Cluster Construction}

On the lower level of facets, there were several patterns that affected cross-cultural differences in a similar way across clusters. First, agentic or personal-growth facets within the clusters tended to be used more often by Whites and less often by Blacks, with Indians in between, with a reversed pattern for communal or social-relational facets. In other words, the agentic-communal distinction was present also within some clusters, in line with theory (Wiggins \& Trapnell, 1996). This was most obvious in Conscientiousness (with facets of achievement vs. order and tradition), Emotional Stability (internalizing vs. externalizing facets), Facilitating (facets focusing on the individual as a guide vs. the beneficial effects of guidance), and Intellect (facets of general vs. social intelligence). Second, there was a general tendency for Blacks to favor facets representing concrete manifestations of personality traits, like in the contrast of concrete aspects of communication versus general communicativeness and extraversion. This pattern was most systematic in the personal-growth clusters and in Integrity. This finding parallels the observation that the three groups differed in a similar way in their use of traits and contextual information: Blacks made the most use of behaviors and contextualizing information, whereas Whites used more traits and less contextualization, with Indians (and Coloureds) in the middle (Valchev et al., 2012). Finally, especially Blacks' personality descriptions often employed characteristics that seem to point to the importance of social norms of behavior. These were social norms in diverse domains, spread across personality clusters: tradition preservation, work and development (with facets in Conscientiousness and Openness), norms of communication in particular, often hierarchical contexts (like frank communication, obedience, and respectfulness, with facets in Extraversion, Conscientiousness, Relationship Harmony, and Soft-Heartedness), and moral norms (in Integrity, although this domain as a whole was more salient for Whites). Norms are societal prescriptions for appropriate behavior and their place in a personality model could be questioned. However, the relevance of norms for personality concepts has been demonstrated in previous indigenous personality research, for example in the case of face-saving and other relational norms in the Chinese context (Cheung et al., 2001). Our study suggests that socialrelational norms, but also norms of tradition, progress, and moral integrity, are an important source of variation in personality concepts in South Africa.

Cross-cultural differences in personality concepts often amount to a lack of replication of Openness and additions to the Agreeableness domain in collectivistic cultures (Church, 2008). A similar pattern applies to our findings, with some qualifications. Rather than failing to observe an Intellect/Openness domain in our more collectivistic Black sample, we found that the broad concepts were present but more often defined in terms of practical and social intelligence and particular interests and activities (cf. Valchev et al., 2011). The replicability of Openness in an African context may thus increase when culture-specific trait manifestations or, in terms of the five-factor theory, characteristic adaptations (McCrae \& Allik, 2002) are taken into account.

The Agreeableness domain, in turn, deserves a careful look. Although our social-relational clusters were found, as expected, to be more salient in the more collectivistic Black group, there was a substantial core of facets that were more salient in the relatively more individualistic White and Indian groups. We interpreted these facets as closer to the core of Agreeableness as it is known in Western models, involving themes of approachability, amiability, and trust. Apart from empathy (which is also a classic element of Agreeableness), the facets overrepresented in Blacks' descriptions involved more specific concepts whose relevance for interpersonal relationships and social harmony was fairly explicit, like guiding others in a beneficial way, maintaining interpersonal relations, gossiping, and generally disruptive behaviors. The finding that members of the more individualistic groups were attentive to aspects of the quality of interpersonal behaviors is not surprising. For example, Durgel, Leyendecker, Yagmurlu, and Harwood (2009) found that 
German mothers placed a higher value than Turkish immigrant mothers on their children's developing close warm relationships. In fact, the individualism-collectivism framework implies that in individualistic cultures it is more important to be able to establish good relationships with foreigners, whereas in collectivistic cultures, the emphasis is more on preserving relationships with in-group members (Triandis, 1995). Our study suggests that there may hence be a core of social-relational personality concepts that are especially salient in individualistic cultures. This may explain the counterintuitive, at first glance, positive association between culture-level Agreeableness and individualism (McCrae et al., 2005). It appears that there is room for expansion of the social-relational domain with concepts beyond this Agreeableness core, which are more salient in collectivistic cultures. Future research should examine the relations between these different groups of social-relational personality concepts in a quantitative framework.

It should be noted that although we treated the Indian group conceptually as intermediate between the other two groups, Indians were closer to Blacks in some cases and to Whites in others, and were the extreme, low or high, group on a number of facets. The facets where the Indian group was extreme were a minority and did not appear to add up to a common pattern. Some of these unexpected findings could be an artifact of the small sample size of this group (although the findings were similar after the inclusion of the Coloured group, not reported here; see Note 3). Nonetheless, this observation should alert us to the fact that the alignment of groups on a single continuum like individualism-collectivism enforces some oversimplification and that when looking beyond common patterns like agency-communion and abstractness-concreteness, differences in the salience of personality concepts can also be expected as a result of more specific cultural factors.

\section{Conclusion}

What are the implications of our findings for the indigenous personality model in South Africa? Given the extensive cross-cultural differences, should this model be treated as a single model or should different models be used for different groups? The strength of the emic-etic approach lies in its ability to allow the representation of both common and specific elements in a unified framework (Cheung et al., 2011). The clusters and subclusters of the South African personality model were based on responses from all 11 languages, and 150 facets were observed in at least seven languages (Nel et al., 2012); the average correlation of .64 across groups in the proportions of facets used per cluster suggested that there is at least a moderate agreement on the meaning of the clusters. There is thus a fair basis to consider the nine-cluster model as common to the three ethnocultural groups. Still, given this common basis, there were systematic differences in the salience of the model's components across groups, both on the broad cluster level and the narrow facet level. Ethnocultural groups in South Africa differ in their preferences for agentic versus communal descriptions, abstract versus specific content, social norms, and relatively culture-specific manifestations of underlying traits. Future studies should establish to what extent the more salient concepts have better predictive validity in different groups.

In conclusion, our study has implications both for personality assessment and for personality theory. With respect to assessment, general factors like the level of abstractness of personality characteristics can affect cross-cultural comparisons (cf. Valchev et al., 2012). When abstractness is a concern, as may often be the case in comparisons between more collectivistic and more individualistic cultures, questionnaire items with specific trait manifestations should be preferred as they have been found to favor structure replicability in more collectivistic groups while not hampering it in more individualistic groups (e.g., Schmitt, Allik, McCrae, \& Benet-Martínez, 2007; Schwartz et al., 2001). With respect to personality theory, our findings suggest that in the implicit personality concepts manifested in free descriptions, there is a noticeable agreement between cultural groups on a common set of concepts similar to the Big Five, but also noticeable 
differences in the emphasis on different components of this set. The expansion of the Big Five space implicates social-relational concepts and diverse social norms. Our study suggests that when the ecological validity of group comparisons is taken seriously, these additional aspects can and should be incorporated in a common model.

\section{Declaration of Conflicting Interests}

The author(s) declared no potential conflicts of interest with respect to the research, authorship, and/or publication of this article.

\section{Funding}

The author(s) disclosed receipt of the following financial support for the research, authorship, and/or publication of this article: The research reported in this article was supported by NRF grant FA20040429900101 and SANPAD grant 09/42.

\section{Notes}

1. The SAPI, an acronym for South African Personality Inventory, is a project that aims to develop an indigenous personality measure for all 11 official languages in South Africa. Participants are Byron Adams (University of Johannesburg, Johannesburg, South Africa, and Tilburg University, Tilburg, the Netherlands), Deon de Bruin (University of Johannesburg), Karina de Bruin (University of Johannesburg), Carin Hill (University of Johannesburg), Leon Jackson (North-West University, Potchefstroom, South Africa), Deon Meiring (University of Pretoria, Pretoria, South Africa, and University of Stellenbosch, Stellenbosch, South Africa), Alewyn Nel (North-West University), Ian Rothmann (North-West University), Michael Temane (North-West University), Velichko Valchev (Tilburg University), and Fons van de Vijver (North-West University, Tilburg University, and University of Queensland, Brisbane, Australia).

2. In addition to the data reported in the present article, the larger SAPI project contained data from 26 Coloureds. Because of the small sample size, we excluded Coloureds from the present study.

3. In a separate set of analyses, Coloureds were included together with Indians as an intermediate group. The outcomes of all analyses were very similar to the ones reported in the present study.

\section{References}

Agresti, A. (2007). An introduction to categorical data analysis (2nd ed.). Hoboken, NJ: Wiley-Interscience.

Allik, J., \& McCrae, R. R. (2004). Toward a geography of personality traits: Patterns of profiles across 36 cultures. Journal of Cross-Cultural Psychology, 35, 13-28.

Ashton, M. C., \& Lee, K. (2001). A theoretical basis for the major dimensions of personality. European Journal of Personality, 15, 327-353.

Cheung, F. M., Leung, K., Zhang, J. X., Sun, H. F., Gan, Y. G., Song, W. Z., \& Xie, D. (2001). Indigenous Chinese personality constructs: Is the Five-Factor Model complete? Journal of Cross-Cultural Psychology, 32, 407-433.

Cheung, F. M., Van de Vijver, F. J. R., \& Leong, F. T. L. (2011). Toward a new approach to the assessment of personality in culture. American Psychologist, 66, 593-603.

Church, A. T. (2001). Personality measurement in cross-cultural perspective. Journal of Personality, 69, 979-1006.

Church, A. T. (2008). Current controversies in the study of personality across cultures. Social and Personality Psychology Compass, 2, 1930-1951.

Del Prado,A. M., Church,A.T., Katigbak, M. S., Miramontes, L. G., Whitty, M.T., Curtis, G. J., , . Reyes, J.A. S. (2007). Culture, method, and the content of self-concepts: Testing trait, individual-self-primacy, and cultural psychology perspectives. Journal of Research in Personality, 41, 1119-1160. 
De Raad, B., Barelds, D. P. H., Levert, E., Ostendorf, F., Mlačić, B., Di Blas, L., . . Katigbak, M. S. (2010). Only three factors of personality description are fully replicable across languages: A comparison of 14 trait taxonomies. Journal of Personality and Social Psychology, 98, 160-173.

De Raad, B., \& Van Heck, G. (1994). The fifth of the Big Five (special issue). European Journal of Personality, 8, 225-356.

DeYoung, C. G., Quilty, L. C., \& Peterson, J. B. (2007). Between facets and domains: 10 aspects of the Big Five. Journal of Personality and Social Psychology, 93, 880-896.

Digman, J. M. (1997). Higher-order factors of the Big Five. Journal of Personality and Social Psychology, 73, 1246-1256.

Durgel, E., Leyendecker, B., Yagmurlu, B., \& Harwood, R. (2009). Sociocultural influences on German and Turkish immigrant mothers' long-term socialization goals. Journal of Cross-Cultural Psychology, 40, 834-852.

Eaton, L., \& Louw, J. (2000). Culture and self in South Africa: Individualism-collectivism predictions. The Journal of Social Psychology, 140, 210-217.

Foxcroft, C. D., Paterson, H., Le Roux, N., \& Herbst, D. (2004). Psychological assessment in South Africa: A needs analysis. Pretoria, South Africa: Human Sciences Research Council.

Ip, G. W. M., \& Bond, M. H. (1995). Culture, values, and the spontaneous self-concept. Asian Journal of Psychology, 1, 30-36.

Katigbak, M. S., Church, A. T., Guanzon-Lapeña, M. A., Carlota, A. J., \& Del Pilar, G. H. (2002). Are indigenous dimensions culture-specific? Philippine inventories and the Five-Factor Model. Journal of Personality and Social Psychology, 82, 89-101.

Laher, S. (2008). Structural equivalence and the NEO-PI-R: Implications for the applicability of the fivefactor model of personality in an African context. SA Journal of Industrial Psychology, 34, 76-80.

Lee, K., \& Ashton, M. C. (2008). The HEXACO personality factors in the indigenous personality lexicons of English and 11 other languages. Journal of Personality, 76, 1001-1053.

Lin, E. J.- L., \& Church, A. T. (2004). Are indigenous Chinese personality dimensions culture-specific? An investigation of the Chinese Personality Assessment Inventory in Chinese American and European American samples. Journal of Cross-Cultural Psychology, 35, 586-605.

McCrae, R. R., \& Allik, J. (Eds.). (2002). The five-factor model of personality across cultures. New York: Kluwer Academic/Plenum.

McCrae, R. R., Terracciano, A., \& 79 Members of the Personality Profiles of Cultures Project. (2005). Personality profiles of cultures: Aggregate personality traits. Journal of Personality and Social Psychology, 89, 407-425.

Meiring, D., Van de Vijver, A. J. R., Rothmann, S., \& Barrick, M. R. (2005). Construct, item, and method bias of cognitive and personality measures in South Africa. SA Journal of Industrial Psychology, 31, 1-8.

Nel, J. A., Valchev, V. H., Rothmann, S., Van de Vijver, F. J. R., Meiring, D., \& De Bruin, G. P. (2012). Exploring the personality structure in the 11 languages of South Africa. Journal of Personality, 80, 915-948.

Ortiz, F. A., Church, A. T., Vargas-Flores, J. J., Ibáñez-Reyes, J., Flores-Galaz, M., Iuit-Briceño, J. I., \& Escamilla, J. M. (2007). Are indigenous personality dimensions culture-specific? Mexican inventories and the Five-Factor Model. Journal of Research in Personality, 41, 618-649.

Paulhus, D. L., \& John, O. P. (1998). Egoistic and moralistic biases in self-perception: The interplay of selfdeceptive styles with basic traits and motives. Journal of Personality, 66, 1025-1060.

Paulhus, D. L., \& Trapnell, P. D. (2008). Self-presentation of personality: An agency-communion framework. In O. P. John, R. W. Robins, \& L. A. Pervin (Eds.), Handbook of personality: Theory and research (3rd ed., pp. 492-517). New York: The Guilford Press.

Roccas, S., Sagiv, L., Schwartz, S. H., \& Knafo, A. (2002). The big five personality factors and personal values. Personality and Social Psychology Bulletin, 28, 789-801. 
Saroglou, V. (2010). Religiousness as a cultural adaptation of basic traits: A Five-Factor Model perspective. Personality and Social Psychology Review, 14, 108-125.

Saucier, G., \& Goldberg, L. R. (2001). Lexical studies of indigenous personality factors: Premises, products, and prospects. Journal of Personality, 69, 847-879.

Schmitt, D. P., Allik, J., McCrae. R. R., \& Benet-Martínez, V. (2007). The geographic distribution of Big Five personality traits: Patterns and profiles of human self-description across 56 nations. Journal of Cross-Cultural Psychology, 38, 173-212.

Schwartz, S. H. (2006). A theory of cultural value orientations: Explication and applications. Comparative Sociology, 5, 136-182.

Schwartz, S. H., Melech, G., Lehmann, A., Burgess, S., Harris, M., \& Owens, V. (2001). Extending the cross-cultural validity of the theory of basic human values with a different method of measurement. Journal of Cross-Cultural Psychology, 32, 519-542.

Sedikides, C., Gaertner, L., \& Toguchi, Y. (2003). Pancultural self-enhancement. Journal of Personality and Social Psychology, 84, 60-79.

Seekings, J. (2008). The continuing salience of race: Discrimination and diversity in South Africa. Journal of Contemporary African Studies, 26, 1-25.

Serpell, R. (1993). The significance of schooling: Life-journeys in an African society. Cambridge, UK: Cambridge University Press.

Statistics South Africa. (2001). Census 2001: Key results. Retrieved from http://www.statssa.gov.za

Tabachnick, B. G., \& Fidell, L. S. (2007). Using multivariate statistics (5th ed.). Boston: Allyn \& Bacon.

Taylor, N., \& De Bruin, G. (2005). Basic Traits Inventory: Technical manual. Johannesburg, South Africa: Jopie van Rooyen \& Partners SA.

Triandis, H. C. (1995). Individualism and collectivism. Boulder, CO: Westview.

Valchev, V. H., Van de Vijver, F. J. R., Nel, J. A., Rothmann, S., Meiring, D., \& De Bruin, G. P. (2011). Implicit personality conceptions of the Nguni cultural-linguistic groups of South Africa. Cross-Cultural Research, 45, 235-266.

Valchev, V. H., Van de Vijver, F. J. R., Nel, J. A., Rothmann, S., Meiring, D., \& De Bruin, G. P. (2012). The use of traits and contextual information in free personality descriptions of ethnocultural groups in South Africa. Manuscript submitted for publication.

Vauclair, C.- M., Hanke, K., Fischer, R., \& Fontaine, J. (2011). The structure of human values at the culture level: A meta-analytical replication of Schwartz's value orientations using the Rokeach Value Survey. Journal of Cross-Cultural Psychology, 42, 186-205.

Watkins, D., \& Gerong, A. (1997). Culture and spontaneous self-concept among Filipino college students. The Journal of Social Psychology, 137, 480-488.

Wiggins, J. S., \& Trapnell, P. D. (1996). A dyadic-interactional perspective on the Five-Factor Model. In J. S. Wiggins (Ed.), The five-factor model of personality: Theoretical perspectives (pp. 88-162). New York: Guilford Press. 